\title{
Role of market information system by traders for gram crop in Bhiwani district of Haryana
}

\author{
Veer Sain* \\ Department of Agricultural Economics, Choudhary Charan Singh Haryana Agricultural \\ University, Hisar -123005 (Haryana), India \\ K.K. Kundu \\ Department of Agricultural Economics, Choudhary Charan Singh Haryana Agricultural \\ University, Hisar -123005 (Haryana), India \\ Anubhuti Mehta \\ Associate Manager (Earnest Young), India \\ Pooja \\ Department of Vegetable Science, Choudhary Charan Singh Haryana Agricultural \\ University, Hisar -123005 (Haryana), India \\ ${ }^{*}$ Corresponding author. E-mail: 3veersain@gmail.com

\begin{abstract}
Cicer arietinum is a suitable crop in Bhiwani district of Haryana covering Siwani and Tosham Blocks were selected purposively on the basis of maximum production under gram crop. Further to study the marketing information and constraints in marketing of gram in Bhiwani, Dadri, Siwani and Tosham markets were selected. For studying the different marketing aspects 40 traders form 4 regulated markets from two blocks of Bhiwani district were randomly selected. From the findings of the research study in Bhiwani district traders, awareness on prices and arrivals in reference/other market and main market were of I-Rank, II-Rank, III-Rank and IV-Rank. Contacts in other markets with fellow traders formed major sources of market information in Bhiwani district. The daily prices were compiled manually and also written on the notices board for the information and use by the farmers visiting the market. The information is disseminated through various media like neighbors, newspapers, relatives etc. About $75 \%$ of the traders in the selected markets also faced difficulty on non-availability of information in required form.
\end{abstract}

Keywords: Bhiwani, Market Information System, Regulated markets, Traders

\section{Article Info}

DOI:10.31018/jans.v10i2.1728

Received: November 22, 2017

Revised: February 26, 2018

Accepted: March 5, 2018

\section{How to Cite}

Sain, V. et al. (2018). Role of market information system by traders for gram crop in Bhiwani district of Haryana. Journal of Applied and Natural Science, 10(2): 528 - 534

\section{INTRODUCTION}

Marketing Information System has four parts, which are Internal Records, Marketing Intelligence, Marketing Research, and Marketing Decision Support System (MDSS). Internal records are the mostly used the information in all the companies around the world such as reports of orders, sales, prices, costs, inventory levels, receivables, payables and so on. According Kotler and Armstrong 2010, Market intelligence system is a set of procedures and sources used by managers to obtain their everyday information about pertinent developments in the marketing environment. Marketing Information Systems as an interacting structure of people, equipments and procedures to gather sort, analyze, evaluate and distribute, timely and right information for use by proper marketing decision makers to improve their marketing design, implementation, and control (Kotler and Keller 2012). Market intelligence system is a set of measures and sources used by managers to obtain their day by day information about related developments in the marketing environment (Kotler and Armstrong, 2010). Information is critical to the social and economic activities that complete the development process. Developing economy has witnessed agricultural (green, white, yellow, blue and now rainbow), industrial and information technology revolutions (Dhankar, G.H. 2003). The Government of India has given more thrust on food and agriculture, information technology sectors towards success of economic reforms for achieving high growth rate in production (Rajendran and Karthikesan, 2014).

Pulses have the capacity to fix atmospheric nitrogen in the soil and are normally rotated with other crops to maintain or restore soil fertility. Though gram and tur/arhar (Cajanus cajan) are the more important pulses, several other pulses such as urd/blackgram (Vigna mungo), mung/greengram (Vigna radiate), masur/lentil (Lens culinaries), kulthi/horsegram (Macrotyloma uniflorum), matar/ peas (Pisum sativum), khesri (Lathyrus sativus) 
and moth (Lepidoptera) are also grown. It can be grown in a wide range of climatic conditions but it prefers mild cool and comparatively dry climate with $20^{\circ}-25^{\circ} \mathrm{C}$ temperature and $40-50 \mathrm{~cm}$ rainfall. It is cultivated as pure or mixed with wheat, barley, linseed or mustard. Gram was grown, currently, in an area of 55 thousand ha, with production of 42 thousand tonnes and productivity of $646 \mathrm{~kg} /$ ha during 2015-16. The present study focuses on the existing market information system, pattern and extent of dissemination and utilization of existing formal information by stakeholders, and the constraints in the existing formal information system and suggests alternatives.

\section{MATERIALS AND METHODS}

The present study based on the information on prices, arrivals, dissemination, utilization and constraints has been carried out on the basis of primary sources were collected by personnel interview method by using pre-tested structured schedule prepared for the purpose. Bhiwani district was purposively selected due to maximum production under Gram. In Bhiwani district two blocks (Siwani and Tosham) were selected due to the maximum area. From Bhiwani district four regulated markets were selected due to maximum arrivals of Bhiwani. From two blocks four markets were randomly selected. Interview method was developed to get complete and reliable information with the help of well-structured schedule. To study the sources of agriculture market information and their utilization among the 40 traders from regulated market were selected for the study based on stratified random sampling technique. To understand the market information system for agricultural commodities, traders, tabular analysis was carried out nature, extent, sources and utilization of the market information system by traders were studied. The farmers response was scored giving a weight of 3 for 'always', 2 for 'sometime', 1 for 'rarely' and 1 for 'yes' and 0 for 'No (Steple and Likar scale method)'.

\section{RESULTS AND DISCUSSION}

Traders awareness on agricultural market information system in Bhiwani district of Haryana: It was revealed from the Table 1 that in general, the degree of awareness of market information was found to be high among the sample traders. Among the different components of market information, the awareness on prices and arrivals in reference/other market formed I-Rank and II-Rank, arrivals and prices in main market (IIIRank) in Bhiwani district. It is worth noting that more than 75 percent of traders were aware of arrivals and prices regularly. It was observed that traders were aware of a market information system on the area under crop production of agricultural products. Similar findings were also reported by Hatai and Panda (2015) in region of Meghalaya.

Sources of regulated market information system for traders in Bhiwani district of Haryana: Table 2. revealed that contacts in other markets and fellow traders formed major sources of market information on arrivals and prices among traders with I and II ranks among different sources of market information. Always more than 70 percent of traders were sourcing their market information through fellow traders and contacts in other markets regularly in Bhiwani district markets. Newspaper (III-rank) was in Bhiwani district, display boards in APMC (IV-rank) in Bhiwani district of markets, bulletins of APMC (VI-rank) was in Bhiwani district of markets, magazines was the other important sources of market information to the traders. Similar findings were also reported by Amrutha and Hugar (2009) in region of Karnataka and Hatai and Panda (2015) in region of Meghalaya.

Pattern of dissemination of market information Mode and frequency of dissemination: The data related to market analysis indicated different modes of dissemination of the market information in all the four markets of Bhiwani district. The market information was transmitted through notice boards, announcements in market yards, fax, phone, All India Radio (AIR), television and newspapers (Table 3). The market information was disseminated daily to the District Information Officer, AIR, newspaper, television, internet and District Statistical Officer. Whereas, it was transmitted to Haryana State Agriculture Marketing Board (HSAMB) on the weekly, monthly and annual basis, similarly, the market information was also sent to Gram/Zilla Panchayat, Agriculture Research Station and Deputy Commissioner once in a year in the form of annual reports (Table 4). Similar findings were also reported by Amrutha and Hugar (2009) in region of Karnataka and Hatai and Panda (2015) in region of Meghalaya.

Utilization and pattern of utilization by traders: Table 5. Indicated that the extent of utilization of agricultural market information by traders for decision making on price to be quoted and the quantity to be purchased, followed by storage decisions of quantity to be sold and the time of storage. It was clearly seen that the agricultural market information was utilized by traders in deciding the price to be quoted (I-Rank), followed by the quantity to be purchased (II-Rank) in Bhiwani district and quantity to be a store (III-Rank) in Bhiwani district. The traders were have utilized market information for making decision on when to sale (V-Rank), when to store (VI-Rank) and followed by quantity to be sold (IV-Rank) in Bhiwani district. Similar findings were also reported by Hatai and Panda (2015) in region of Meghalaya.

Benefits derived from market information by 
Sain V. et al. / J. Appl. \& Nat. Sci. 10 (2): 528 - 534 (2018)

Table 1. Traders awareness of regulated market information in Bhiwani district of Haryana.

\begin{tabular}{|c|c|c|c|c|c|c|c|c|c|}
\hline \multirow{3}{*}{$\begin{array}{l}\text { S. } \\
\text { N. }\end{array}$} & \multirow{3}{*}{$\begin{array}{l}\text { Type of market infor- } \\
\text { mation }\end{array}$} & \multicolumn{8}{|c|}{ Degree of Awareness } \\
\hline & & \multicolumn{2}{|l|}{ Always } & \multicolumn{2}{|c|}{ Sometime } & \multicolumn{2}{|l|}{ Rarely } & \multirow[b]{2}{*}{ Total } & \multirow[b]{2}{*}{ Rank } \\
\hline & & Score & $\begin{array}{l}\text { Per- } \\
\text { centage }\end{array}$ & Score & $\begin{array}{l}\text { Per- } \\
\text { centage }\end{array}$ & Score & $\begin{array}{l}\text { Percent- } \\
\text { age }\end{array}$ & & \\
\hline 1 & $\begin{array}{l}\text { Arrivals in reference/ } \\
\text { other market (Bhiwani } \\
\text { and Dadri) }\end{array}$ & $\begin{array}{l}37 \\
(92.5)\end{array}$ & 111 & $\begin{array}{l}3 \\
(7.5)\end{array}$ & 6 & $\begin{array}{l}0 \\
(00.0)\end{array}$ & 0 & 117 & II \\
\hline 2 & $\begin{array}{l}\text { Arrivals in main market } \\
\text { (Tosham and Siwani) }\end{array}$ & $\begin{array}{l}29 \\
(72.5)\end{array}$ & 87 & $\begin{array}{l}11 \\
(27.5)\end{array}$ & 22 & $\begin{array}{l}0 \\
(00.0)\end{array}$ & 0 & 109 & III \\
\hline 3 & $\begin{array}{l}\text { Prices in reference/ } \\
\text { other market (Bhiwani } \\
\text { and Dadri) }\end{array}$ & $40(100)$ & 120 & $\begin{array}{l}0 \\
(00.0)\end{array}$ & 0 & $\begin{array}{l}0 \\
(00.0)\end{array}$ & 0 & 120 & I \\
\hline 4 & $\begin{array}{l}\text { Prices in main market } \\
\text { (Tosham and Siwani) }\end{array}$ & $\begin{array}{l}29 \\
(72.5)\end{array}$ & 87 & $\begin{array}{l}11 \\
(27.5)\end{array}$ & 22 & $\begin{array}{l}0 \\
(00.0)\end{array}$ & 0 & 109 & III \\
\hline 5 & Area under crops & $\begin{array}{l}24 \\
(60.0)\end{array}$ & 72 & $\begin{array}{l}15 \\
(37.5)\end{array}$ & 30 & $\begin{array}{l}1 \\
(2.5)\end{array}$ & 1 & 102 & VI \\
\hline 6 & Production & $\begin{array}{l}20 \\
(50.0)\end{array}$ & 60 & $\begin{array}{l}10 \\
(25.0)\end{array}$ & 20 & $\begin{array}{l}10 \\
(25.0)\end{array}$ & 10 & 90 & V \\
\hline 7 & $\begin{array}{l}\text { Grade/Standard } \\
\text { quired }\end{array}$ & $\begin{array}{l}15 \\
(50.0)\end{array}$ & 45 & $\begin{array}{l}18 \\
(45.0)\end{array}$ & 36 & $\begin{array}{l}7 \\
(17.5)\end{array}$ & 7 & 88 & VI \\
\hline
\end{tabular}

Figures in the parentheses indicate percentages to total; Always $=3$, Sometime $=2$, Rarely $=1 ; \mathrm{N}=40$

Table 2. Sources of regulated market information system for trader in Bhiwani district of Haryana.

\begin{tabular}{|c|c|c|c|c|c|c|c|c|c|}
\hline \multirow{3}{*}{$\begin{array}{l}\text { S. } \\
\text { N. }\end{array}$} & \multirow[t]{3}{*}{ Sources } & \multicolumn{8}{|c|}{ Degree of Awareness } \\
\hline & & \multicolumn{2}{|l|}{ Always } & \multicolumn{2}{|c|}{ Sometime } & \multicolumn{2}{|l|}{ Rarely } & \multirow{2}{*}{$\begin{array}{l}\text { Total } \\
\text { score }\end{array}$} & \multirow[t]{2}{*}{ Rank } \\
\hline & & Response & Score & Response & Score & Response & Score & & \\
\hline 1 & Newspaper & $10(25.0)$ & 30 & $14(35.0)$ & 28 & $16(40.0)$ & 16 & 74 & III \\
\hline 2 & Television & $5(12.5)$ & 15 & 7 (17.5) & 14 & $28(70.0)$ & 28 & 57 & $x$ \\
\hline 3 & Radio & $4(10.0)$ & 12 & $8(20.0)$ & 16 & $28(70.0)$ & 28 & 56 & $\mathrm{XI}$ \\
\hline 4 & Magazine & $6(15.0)$ & 18 & $14(35.0)$ & 28 & $20(50.0)$ & 20 & 66 & $\mathrm{~V}$ \\
\hline 5 & Internet & $6(15.0)$ & 18 & $12(30.0)$ & 24 & $22(55.0)$ & 22 & 64 & VI \\
\hline 6 & Fellow traders & $32(80.0)$ & 96 & $6(15.0)$ & 12 & $2(5.0)$ & 2 & 110 & II \\
\hline 7 & $\begin{array}{l}\text { Contact in other } \\
\text { market }\end{array}$ & $34(85.0)$ & 102 & $6(15.0)$ & 12 & $0(00.0)$ & 0 & 114 & I \\
\hline 8 & $\begin{array}{l}\text { Announcement } \\
\text { by APMC }\end{array}$ & $6(15.0)$ & 18 & $14(35.0)$ & 28 & $20(50.0)$ & 20 & 66 & V \\
\hline 9 & $\begin{array}{l}\text { Govt. publica- } \\
\text { tions }\end{array}$ & $4(10.0)$ & 12 & $11(27.5)$ & 22 & $25(62.5)$ & 25 & 59 & IX \\
\hline 10 & $\begin{array}{l}\text { Display board in } \\
\text { APMC }\end{array}$ & 7 (17.5) & 21 & $13(32.5)$ & 26 & $20(50.0)$ & 20 & 67 & IV \\
\hline 11 & $\begin{array}{l}\text { Bulletins by } \\
\text { APMC }\end{array}$ & $6(15.0)$ & 18 & $12(30.0)$ & 24 & $22(55.0)$ & 22 & 64 & $\mathrm{VI}$ \\
\hline 12 & $\begin{array}{l}\text { Market Intelli- } \\
\text { gence Cell }\end{array}$ & $4(10.0)$ & 12 & $6(15.0)$ & 12 & $30(75.0)$ & 30 & 54 & XII \\
\hline 13 & $\begin{array}{l}\text { APMC tender } \\
\text { data for previ- } \\
\text { ous days }\end{array}$ & $5(12.5)$ & 15 & $11(27.5)$ & 22 & $24(60.0)$ & 24 & 61 & VIII \\
\hline
\end{tabular}

Figures in the parentheses indicate percentages to total; Always $=3$, Sometime $=2$, Rarely $=1 ; \mathrm{N}=40$

traders: Table 6. indicated that the benefits from Bhiwani district of traders have derived as per their opinion by utilizing market information. It revealed that traders were benefited and obtained higher price by utilizing the market information's system. It was observed that traders were most benefited by changing time of sale $(85.0 \%)$, followed by changing the place of sale $(75.0 \%)$, followed by mode of storage $(70.0 \%)$, followed by drying of produce $(60.0 \%)$ in Bhiwani district of markets. Similar findings were also reported by Hatai and Panda (2015) in region of Meghalaya.

Constraints, expectations and suggestions of stakeholder on market information's constraints faced by traders: The constraints as perceived by traders were presented in Table 7 . About $(80.0 \%)$ of farmers expressed that market information was not available in required form in Bhiwani district. Traders were also faced difficulty on non- 
Table 3. Dissemination of market information in Bhiwani district markets of Haryana.

\begin{tabular}{lccc}
\hline $\begin{array}{l}\text { Sr. } \\
\text { No. }\end{array}$ & $\begin{array}{c}\text { Mode of } \\
\text { dissemination }\end{array}$ & Score & Percentage \\
\hline 1 & Notices board & 4 & 100.0 \\
2 & Announcement & 4 & 100.0 \\
3 & Fax & 4 & 100.0 \\
4 & Telephone & 4 & 100.0 \\
5 & Internet & 4 & 100.0 \\
6 & AlR & 4 & 100.0 \\
7 & Television & 4 & 100.0 \\
8 & Posts & 4 & 100.0 \\
9 & Newspaper & 4 & 100.0 \\
\hline
\end{tabular}

$\mathrm{N}=4$

availability of required information on price/ prices in other markets/ production aspect $(65.0 \%)$, followed by Non-availability in time aspect $(50.0 \%)$, followed by accessibility aspects $(40.0 \%)$, followed by Inadequate network system aspect $(50.0 \%)$, followed by followed by lack of information in an barrier production aspect (45.0\%), followed by lack of proper dissemination of market Intelligence through communication $(35.0 \%)$ in Bhiwani district. Similar findings were also reported by Sankar and singh (2014) in region of Uttarakhand.

Constraints faced by markets: The constraints in the existing market information in different market committees were presented in Table 8. About (100.0\%) of market expressed a maximum number of non availability of trained personnel was in Bhiwani district. Members of different markets committee persons faced difficulty in compilation was $(100.0 \%)$, followed by lack of awareness was (100.0\%), followed by Insufficient personnel was $((100.0 \%)$ in Bhiwani district. Similar findings were also reported by Sankar and singh (2014) in region of Uttarakhand. Expectations of stakeholders: The commodities trader's expectations of market information as given in Table 9 clearly indicated that the projections on price/ future price movement was $(100.0 \%)$ in Bhiwani district. Price in other nearby market was $(100.0 \%)$, followed by variety wise prices $(92.5 \%)$, followed by post harvest handling technique was $(82.5 \%)$ in Bhiwani district. Similar findings were also reported by Hatai and Panda (2015) in region of Meghalaya.

The different study conducted so far related with present study revealed that Market Information
System is a process of gathering, processing, storing and using information to make better marketing decisions and to improve marketing exchange. Agricutlure marketing information system network (Agmarknet) in India and found that almost all the states and union territories were given that market information in one form or the other for the advantage of market users like producers, traders and consumers. However, the information was collected and disseminated by conventional methods which caused undue delay in communicating the information to different target groups, and thus adversely affecting their economic interest. Therefore, it was a requirement to get better the present market information system by linking all agricultural produce market committees/ wholesale markets, state agricultural marketing boards and directorates of marketing and inspection (DMI) with the ministry of agriculture for effective and efficient information exchange. Lack of information was an entry barrier to both production and trade.

Conventionally, the markets maintained information in the form of registers. The daily prices were compiled manually and written on the blackboards for the use of farmers visiting the markets. The information was disseminated through various media like radio, neighour, newspapers and blackboard at market yards. The utility of market information was low among the farmers as compared to traders. The benefit derived in the form of obtaining higher price by traders was relatively higher as compared to the benefits derived by farmers whereas, my study reveal the similar facts.

\section{Conclusion}

Based on following finding of the study for improving the agricultural marketing information system in Bhiwani district traders of Haryana. Awareness of traders was very effectively in Bhiwani district. None of the selected district farmers was aware of either area, production, quality of produce or scientific post harvest handling of the produce. Traders were aware of information on these aspects besides details of the produce in Bhiwani district markets. Contacts in other markets and fellow traders were the major source of the market information to the traders of selected district markets. The modes of dissemination of market information were the traditional announcements, display

Table 4. Distribution of market information to different agencies in Bhiwani district markets of Haryana.

\begin{tabular}{llll}
\hline S. N. & Mode of dissemination & Score & Percentage \\
\hline 1 & State Agricultural Marketing Board & 4 & 100.0 \\
2 & Department of Agriculture & 4 & 100.0 \\
3 & District Statistical Offices & 4 & 100.0 \\
4 & Research Station & 4 & 100.0 \\
5 & Newspapers & 4 & 100.0 \\
6 & Gram Panchayat & 2 & 50.0 \\
\hline $\mathrm{N}=4$ & & & \\
\hline
\end{tabular}


Sain V. et al. / J. Appl. \& Nat. Sci. 10 (2): 528 - 534 (2018)

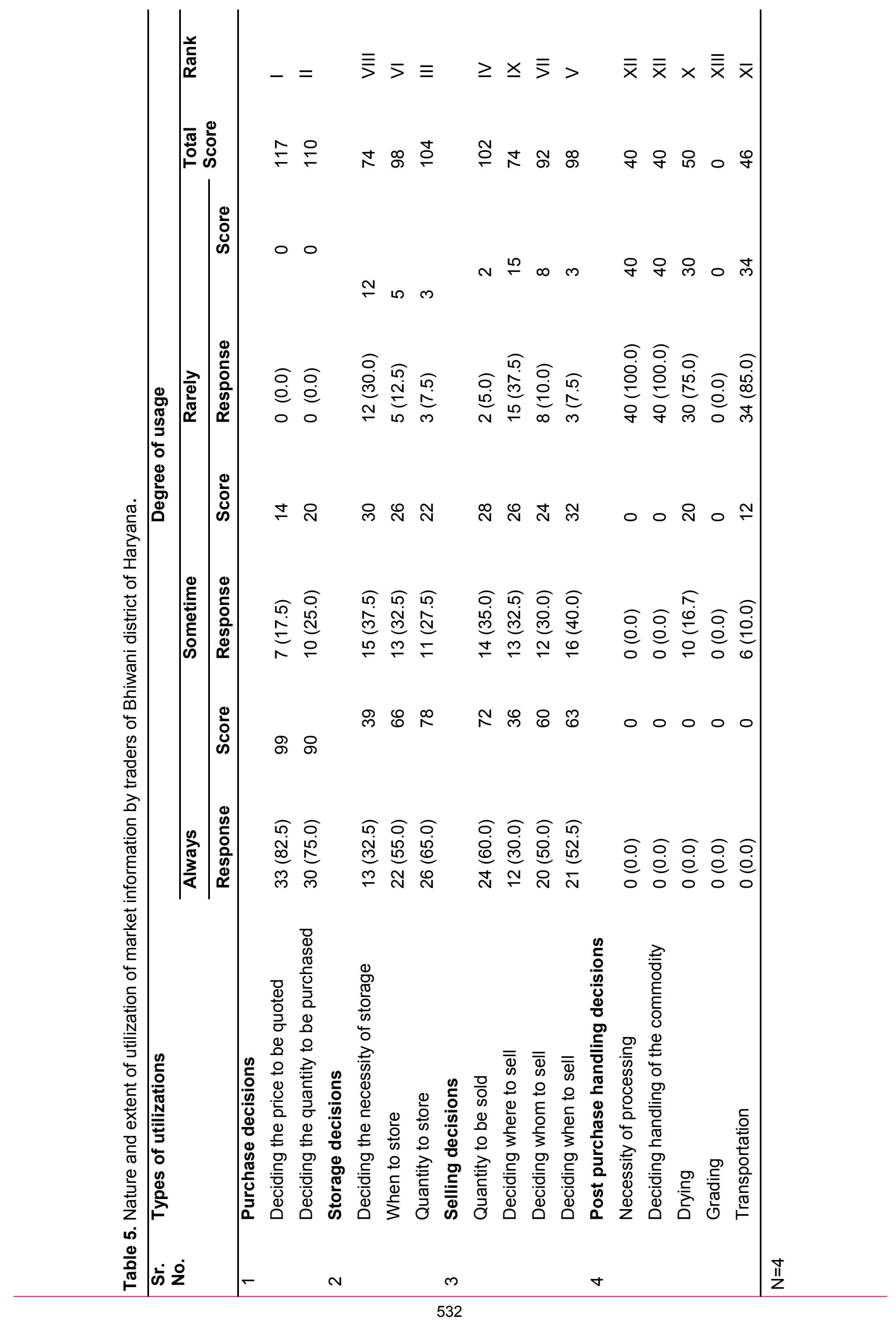


Table 6. Benefits derived from agricultural market information by traders in Bhiwani district of Haryana.

\begin{tabular}{llll}
\hline Sr. No. & Types of benefits from market information system & No. & Percentage \\
\hline Obtained higher price & & \\
\hline 1 & Changing place of sale & 30 & 75.0 \\
2 & Changing time of sale & 34 & 85.0 \\
3 & Changing post harvest handling & 14 & 35.0 \\
4 & Drying of produce & 24 & 60.0 \\
5 & Mode of packing & 18 & 45.0 \\
6 & Mode of storage & 28 & 70.0 \\
7 & Changing quantity of sale & 16 & 40.0 \\
8 & Changing buyer & 14 & 35.0 \\
\hline $\mathrm{N}=40$ & & \multicolumn{3}{l}{}
\end{tabular}

Table 7. Constraints in management of market information in Bhiwani district markets of Haryana.

\begin{tabular}{llll}
\hline Sr. No. & Constraints & No. & Percentage \\
\hline $\mathbf{1}$ & Lack of awareness & 8 & 100.0 \\
$\mathbf{2}$ & Insufficient personnel & 8 & 100.0 \\
$\mathbf{3}$ & Non availability of trained personnel & 8 & 75.0 \\
$\mathbf{4}$ & Time consuming & 6 & 75.0 \\
$\mathbf{5}$ & Difficulty in compilation & 8 & 100.0 \\
\hline
\end{tabular}

Table 8. Constraints as perceived by traders in existing Agriculture Marketing Information's of Bhiwani district of Haryana.

\begin{tabular}{llll}
\hline Sr. No. & Constraints & No. & Percentage \\
\hline $\mathbf{1}$ & Information available but not accessible & 16 & 40.0 \\
$\mathbf{2}$ & Costly & 6 & 15.0 \\
$\mathbf{3}$ & Non- availability in time & 20 & 50.0 \\
$\mathbf{4}$ & Non-availability of required information on price/ price in other & 26 & 65.0 \\
& markets/ arrival/ area/ production & 30 & 75.0 \\
$\mathbf{5}$ & Non-availability of information in required form & 20 & 50.0 \\
$\mathbf{6}$ & Inadequate Network for Information flow & 18 & 45.0 \\
$\mathbf{7}$ & Lack of information is an barrier production and traders & 35.0 \\
$\mathbf{8}$ & Lack of Proper dissemination of Market Intelligence through com- & 14 & 3 \\
& munication & &
\end{tabular}

$\mathrm{N}=40$

Table 9. Expectation of agricultural commodities traders on market information of Bhiwani district.

\begin{tabular}{llll}
\hline Sr. No. & Constraints & No. & Percentage \\
\hline $\mathbf{1}$ & Projections on prices/ future price movement & 38 & 95.0 \\
$\mathbf{2}$ & Prices in other nearby markets & 40 & 100.0 \\
$\mathbf{3}$ & Variety wise prices & 37 & 92.5 \\
$\mathbf{4}$ & Post harvest handling information for better price & 33 & 82.5 \\
\hline
\end{tabular}

$\mathrm{N}=40$

boards, transmission through television and newspapers of Bhiwani district markets. The utility of market information was good among the traders of Bhiwani district markets. The benefit derived in the form of higher price by traders was relatively effectively of Bhiwani district markets. The traders opined that they had difficulty in obtaining the information in the required form. The markets were facing the constraint of inadequate personnel of Bhiwani district markets. The trader's expectations were on area and production information followed by price projections of Bhiwani district markets. The MIS should be deliver fast, reliable and accurate information in a user friendly manner for utilization by the farmers and other stakeholders in order to facilitate the farmers to decide what and when make crop and marketing planning, how to cultivate, when and how to harvest, what post harvest management practices to follow, when, where, how to sell etc. of the agricultural produce in the study area.

\section{REFERENCES}

Amrutha, C. F. and Hugar, L.B. (2009). An economic analysis of dissemination and utilization of market information on onion in Karnataka. International Journal of Commerce and Business Mangement. 2 (2): 132-135.

Amrutha, T.J., Siddayya and Reddy, S.V. (2015). A comparative study on use of Electronic devices in agricultural marketing in Nek region. Indian Journal. 
Sain V. et al. / J. Appl. \& Nat. Sci. 10 (2): 528 - 534 (2018)

of Agricultural.Marketing., 29 (1):1-20.

Dhankar, G. H. (2003). Development of internetbased agricultural marketing system in India. Agricultural Marketing 45 (4) : 7-16.

Hatai, L.D. and Panda, D. (2015). Agricultural Marketing Information System: A Case Study of Traders in Meghalaya. Economic Affairs, 60 (2):263-271.

Rajendran, G. and Karthikesan, P. (2014). Agricultural marketing in India-an overview. Asia Pacific. J.ournal Res. 1: 159-164.
Kotler,P. and Armstrong,G. (2010). Principle of Marketing, 13th edition, New Jersey, Prentice Hall International.

Kotler,P. and Keller,K. (2012). Marketing Management, 14th edition, Englewood Cliffs NJ, Prentice Hall International.

Sankar, M.S. and Singh, A. (2014). Agricultural Produce Market Committee (APMC) Act in Uttarakhand and its Impact on Agribusiness. International Journal of Marketing and Technology. 4 (4): 189-203. 